\title{
Pengaruh Pijat Bayi terhadap Peningkatan Berat Badan
}

\author{
Yuyuk Eva Fitriyanti ${ }^{1 *}$, Gusman Arsyard ${ }^{1}$, Sumiaty ${ }^{2}$ \\ ${ }^{1}$ Prodi DIV Kebidanan Jurusan Kebidanan Poltekkes Kemenkes Palu, \\ ${ }^{2}$ Prodi DIII Kebidanan Jurusan Kebidanan Poltekkes Kemenkes Palu \\ *Email korespondensi: yuyukeva24@gmail.com
}

\section{$\begin{array}{ll}\text { Article Info } & \text { ABSTRACT }\end{array}$}

Article history:

Submitted: 2019-07-10

Accepted: 2019-08-28

Published: 2019-08-31

Keywords:

Massage; Baby; Weight;
Indicator of child growth is weight. At the age of 1-3 months is a period of rapid growth, so it is necessary to maintain a baby's weight according to age. Touch therapy or massage is one of technique that combines the physical benefits of human touch with emotional benefits such as bounding and increasing weight. The purpose of this study was to determine the effect of infant massage on weight gain in infants aged 1 3 months in the work area of the Sangurara Health Center in Palu. This type of research was a Quasi-experimental design with pretest and Posttest control group design. The sample in this study was 30 months old infants as many as 30 infants with sampling technique consecutive sampling. Data analysis used test Chi-square with a confidence level of $95 \%(\alpha=0.05)$. The results show that babies who were massaged had more weight gain, which was $24.07 \%$, while babies who were not massaged had a weight gain of $18.28 \%$. This is evidenced by the value of $p$ value: 0.03 (p.value $\leq 0.05$ ). In conclusion, there was the effect of Baby Massage on Increased Body Weight. Suggestions for researchers for health workers to socialize and suggest baby massage to reduce the case of BGM weight (Under the Red Line) in infants.

\footnotetext{
ABSTRAK

Kata Kunci:

Pijat; Bayi; Berat Badan;

Indikator pertumbuhan anak adalah berat badan. Pada usia 1-3 bulan merupakan masa pertumbuhan yang cepat, sehingga perlu menjaga berat badan bayi sesuai umur. Touch therapy atau massage (pemijatan) adalah salah satu teknik yang mengombinasikan manfaat fisik sentuhan manusia dengan manfaat emosional seperti ikatan batin (bounding) dan peningkatan berat badan.Tujuan penelitian ini adalah untuk mengetahui pengaruh pijat bayi terhadap peningkatn berat badan pada bayi usia 1-3 bulan di wilayah kerja Puskesmas Sangurara Kota Palu. Jenis penelitian ini adalah Quasy exsperimen dengan rancangan Pretest dan Postest control group design dan besar sampel 30 bayi usia 1-3 bulan. Jenis pengambilan sampel menggunakan consecutive sampling. Analisis data menggunakan uji Chi-square dengan tingkat kepercayaan 95\% $(\alpha=0,05)$. Hasil penelitian menunjukkan bahwa bayi yang dipijat lebih banyak mengalami peningkatan berat badan yaitu $24,07 \%$, sedangkan bayi tidak dipijat mengalami peningkatan berat badan sebanyak $18,28 \%$. Hasil uji statistik menunjukkan pengaruh pijat bayi terhadap peningkatan berat badan. Hal ini dibuktikan dari nilai $p$ value: 0,03 (p.value $\leq 0,05$ ). Kesimpulannya terdapat pengaruh pijat bayi terhadap peningkatan berat badan di wilayah kerja Puskesmas Sangurara. Saran peneliti bagi petugas kesehatan agar mensosialisasikan, mengajarkan dan menganjurkan pijat bayi untuk mengurangi kasus berat badan BGM (Bawah Garis Merah) pada bayi.
} 


\section{PENDAHULUAN}

Pertumbuhan adalah pertambahan ukuran dan jumlah sel. Pertumbuhan bersifat kuantitatif sehingga dapat diukur menggunakan satuan berat atau panjang seperti berat badan atau tinggi badan. Perkembangan adalah peningkatan kemampuan/skill yang kompleks dengan pola yang teratur dan dapat diduga sebagai maturasi susunan saraf pusat termasuk juga perkembangan emosi, intelektual dan tingkah laku sebagai hasil interaksi dengan lingkung. ${ }^{1}$ Pertumbuhan dan perkembangan perlu diupayakan untuk menjaga agar berat badan normal sesuai umur, dengan cara memenuhi kebutuhan gizi secara kuantitas maupun kualitas, menjaga lingkungan yang kondusif dengan membuat suasana tempat tinggal yang nyaman dan sanitasi yang baik, menjaga kesehatan bayi dengan memberi imunisasi dan kontrol ke pelayanan kesehatan serta memberikan stimulus. Stimulus yang diberikan berupa stimulus taktil yaitu pijat bayi karena dengan pijat dapat merangsang otototot, tulang dan sistem organ berfungsi secara maksimal. ${ }^{2}$

Berdasarkan hasil survey demografi dan kesehatan Indonesia (SDKI) tahun (2017) menunjukkan jumlah bayi di Indonesia mencapai 14.261.868 jiwa diantaranya bayi mengalami berat badan Bawah Garis Merah (BGM) presentase 3,5\%. ${ }^{3}$

Data Dinas Provinsi Kesehatan Sulawesi Tengah menunjukkan bahwa jumlah bayi pada tahun (2017) mencapai 60.715 jiwa diantaranya mengalami berat badan Bawah Garis Merah (BGM) presentase 4,7\%.4 Berdasarkan data Dinas Kesehatan Kota Palu (2017) dengan jumlah bayi yang terdata yaitu 7802 jiwa diantaranya mengalami BGM dengan presentase $2,1 \%$ serta bervariasi pada beberapa Puskesmas seperti Puskesmas Talise dengan jumlah bayi 382 jiwa diantaranya mengalami BGM 46 bayi; Puskesmas Sangurara dengan jumlah bayi 908 jiwa diantaranya mengalami BGM 30 bayi; Puskesmas Tipo dengan jumlah bayi 178 jiwa diantaranya mengalami BGM 21 bayi dan Puskesmas Kamonji dengan jumlah bayi 986 jiwa diantaranya mengalami BGM 8 bayi $^{.}$

Inal dan Yildiz (2005) dalam Gurol (2012) menyelidiki efek pijat diterapkan selama 6 bulan pada pertumbuhan bayi dan perkembangan motorik mental. ${ }^{6}$ Hasil signifikan telah ditemukan secara statistik bahwa bayi yang menerima pijatan mengalami peningkatan berat badan dan meningkatkan perkembangan mereka. Berdasarkan hasil penelitian Miah (2010) membuktikan bahwa terdapat pengaruh pijat bayi terhadap kenaikan berat badan bayi umur 10 hari-3 bulan. ${ }^{7}$

Penelitian yang dilakukan oleh T. Field dan Scafidi dari Universitas Miami, Amerika Serikat yang menunjukan bahwa 20 bayi prematur mengalami kenaikan berat badan 20-47\% per hari setelah dipijat $3 \times 15$ menit selama 10 hari. Bayi usia 1-3 bulan yang mengalami kenaikan berat badan dipijat dua kali seminggu dengan durasi 15 menit selama enam minggu mengalami kenaikan berat badan yang pesat dari kelompok bayi yang tidak dipijat. Bayi yang dipijat mengalami peningkatan tonus nerous vagus (saraf otak ke-10). Hal ini membuat kadar enzim penyerapan gastrin dan insulin meningkat, sehingga penyerapan terhadap sari makanan menjadi lebih baik dan menyebabkan bayi mudah lapar.8

Bayi yang dilakukan pemijatan akan memberikan efek lapar pada bayi sehingga frekuensi menyusu bayi akan lebih sering. Hal itu disebabkan karena peningkatan tonus otot saraf vagus. Tonus ini menyebabkan cabang dari saraf vagus tersebut memudahkan pengeluaran hormon penyerapan makanan dan meningkatkan kadar enzim penyerapan gastrin dan insulin. Oleh sebab itu, penyerapan terhadap sari makanan akan lebih baik sehingga bayi yang dipijat akan mengalami kenaikan berat badan yang lebih pesat. ${ }^{9}$ 
Berdasarkan data-data diatas maka peneliti tertarik melakukan penelitian di wilayah Kerja Puskesmas Sangurara yang merupakan wilayah dengan jumlah bayi terbanyak kedua dan kasus berat badan Bawah Garis Merah teringgi kedua di Kota Palu, sehingga peneliti akan melakukan penelitian tentang pengaruh pijat bayi terhadap peningkatan berat badan di wilayah kerja Puskesmas Sangurara. Tujuan penelitian ini adalah diketahui pengaruh pijat bayi terhadap peningkatan berat badan di wilayah kerja Puskesmas Sangurara.

\section{METODE PENELITIAN}

Penelitian ini menggunakan metode Quasy exsperimen dengan rancangan Pretest dan Postest control group design. Variable yang diteliti adalah pengaruh pijat bayi terhadap peningkatan berat badan di wilayah kerja Puskesmas Sangurara. Waktu penelitian ini dilakukan pada 21 September 2018-28 Juni 2019, sedangkan pengumpulan data penelitian dilakukan pada 07 Maret-07 Mei 2019. Populasi dalam penelitian ini adalah bayi usia 1-3 bulan di wilayah kerja Puskesmas Sangurara dengan jumlah 74 bayi. Jumlah sampel penelitian ditentukan menggunakan rumus Lemeshow yaitu 30 bayi yang terbagi menjadi dua kelompok yaitu 15 bayi kelompok intervensi dan 15 bayi kontrol. Teknik pemilihan sampel secara consecutive sampling tanpa ada proses matching. Adapun kriteria inklusi adalah bayi berusia 1-3 bulan, bayi yang diberi asupan ASI, orang tua bayi bersedia untuk berpartisipasi, bayi tidak dengan kelainan bawaan, bayi yang sedang tidak dalam keadaan sakit. Data dikumpulkan melalui pengukuran (penimbangan) dan observasi yang dilakukan oleh peneliti. Responden yang memenuhi kriteria peneliti akan diambil sebagai subjek penelitian dan di masukkan dalam kelompok intervensi atau kelompok observasi, setiap responden yang termaksud kelompok intervensi akan mengisi lembar karakteristik responden dan dilakukan penimbangan kemudian dilakukan pijat bayi mengikuti panduan SPO pijat bayi yang dilakukan oleh bidan yang memiliki sertifikat, sebanyak 3 kali dalam seminggu selama 1 bulan dan akan diobersevasi penimbangan berat badan setelah 1 bulan. Sedangkan kelompok kontrol dilakukan penimbangan berat badan awal dan akhir setelah 1 bulan. Analisis data menggunakan uji statistik Chi-Square (uji nonparametrik) untuk tabel $2 \times 2$.

\section{HASIL PENELITIAN}

Setelah data penelitian dianalisis maka diperoleh hasil sebagai berikut:

\section{Hasil Analisis Univariat}

Tabel 1:Distribusi karakteristik responden berdasarkan umur dan jenis kelamin Bayi pada kelompok intervensi/ pijat di Wilayah kerja Puskesmas Sangurara

\begin{tabular}{lcc}
\hline \multicolumn{1}{c}{ Variabel } & Frekuensi & $\%$ \\
\hline Umur & 5 & \\
1 Bulan & 6 & 33.3 \\
2 Bulan & 4 & 40.0 \\
3 Bulan & & 26.7 \\
Jenis Kelamin & 6 & 40.0 \\
Laki-laki & 9 & 60.0 \\
Perempuan & 15 & 100.0 \\
\hline Total & & \\
\hline
\end{tabular}


Berdasarkan Tabel 1 bahwa kelompok umur pada responden kelompok intervensi/pijat terbanyak umur 2 bulan sebanyak $40,0 \%$, kategori jenis kelamin yang dominan yaitu perempuan sebanyak $60,0 \%$.

Tabel 2: Distribusi karakteristik responden berdasarkan umur Bayi pada kelompok Kontrol/ Tidak dipijat di Wilayah kerja Puskesmas Sangurara
Variabel
Frekuensi $\%$

\begin{tabular}{lcc}
\hline Umur & 6 & \\
1 Bulan & 4 & 40.0 \\
2 Bulan & 5 & 26.7 \\
3 Bulan & & 33.3 \\
Jenis Kelamin & 12 & 80.0 \\
Laki-laki & 3 & 20.0 \\
Perempuan & 15 & 100.0 \\
\hline \multicolumn{1}{c}{ Total } &
\end{tabular}

Berdasarkan Tabel 2 bahwa kelompok umur pada responden kelompok kontrol/tidak dipijat terbanyak umur 1 bulan sebanyak 40,0\%, kategori jenis kelamin yang dominan yaitu perempuan sebanyak $80,0 \%$.

Tabel 3: Distribusi berat badan pada kelompok intervensi/pijat dan kelompok kontrol/tidak dipijat

\begin{tabular}{lcc}
\hline \multicolumn{1}{c}{ Variabel } & Frekuensi & $\%$ \\
\hline Kelompok Intervensi/pijat & & \\
Berat badan normal & 5 & 33,3 \\
Berat badan Meningkat & 10 & 66,7 \\
\hline \multicolumn{1}{c}{ Total } & 15 & 100 \\
\hline Kelompok kontrol/tidak dipijat & 13 & 86,7 \\
Berat badan normal & 2 & 13,3 \\
\hline Berat badan Meningkat & 15 & 100 \\
\hline \multicolumn{1}{c}{ Total } & &
\end{tabular}

Berdasarkan Tabel 3 diketahui bahwa kelompok intervensi/pijat cenderung dalam kategori berat badan meningkat sebanyak 66,7 \%, sedangkan kelompok kontrol/tidak dipijat cenderung dalam kategori berat badan normal sebanyak $86,7 \%$.

Tabel 4: Distribusi nilai rata-rata berat badan bayi

\begin{tabular}{llcl}
\hline \multicolumn{1}{c}{ Variabel } & N & Mean & Std. Deviasi \\
\hline Kelompok Intervensi/dipijat & 5 & $1093.33(24,07 \%)$ & 162.422 \\
Kelompok kontrol/tidak dipijat & 5 & $840.00(18,28 \%)$ & 135.225 \\
\hline
\end{tabular}

Berdasarkan Tabel 4 diketahui bahwa nilai rata-rata berat badan bayi pada kelompok dipijat mengalami peningkatan sebanyak $24,07 \%$, sedangkan pada kelompok kontrol/tidak dipijat mengalami peningkatan sebanyak $18,28 \%$. Sehingga dapat dikatakan bahwa bayi yang dipijat memiliki kenaikan berat badan dari pada kelompok kontrol/tidak dipijat.

\section{Hasil Analisis Bivariat}

Analisis bivariat dilakukan untuk mengetahui ada atau tidak pengaruh pijat bayi terhadap peningkatan berat badan. Penelitian ini dilakukan pada bayi usia 1-3 bulan yang memenuhi kriteria yang telah ditentukan oleh peneliti. Dari hasil analisis yang dilakukan menggunakan uji statistic chi-square untuk table $2 \times 2$ dengan derajat kemaknaan $95 \%(\alpha=0,05)$, diperoleh hasil sebagai berikut: 
Tabel 5: Distribusi pengaruh pijat bayi terhadap peningkatan berat badan di wilayah kerja Puskesmas Sangurara Kota Palu.

\begin{tabular}{cccccc}
\hline & \multicolumn{4}{c}{ Berat Badan } & P.value \\
\cline { 2 - 5 } Pijat Bayi & Normal & \multicolumn{4}{c}{ Meningkat } \\
& $\mathrm{F}$ & $\%$ & $\mathrm{~F}$ & $\%$ & \\
\hline Tidak dipijat & 13 & 86,7 & 2 & 13,3 & \multirow{2}{*}{0,03} \\
Pijat & 5 & 33,3 & 10 & 66,7 & \\
\hline
\end{tabular}

Pada Tabel 5 menunjukkan bahwa bayi yang diberikan intervensi/dipijat lebih cenderung mengalami peningkatan terhadap berat badan sebanyak $66,7 \%$, sedangkan pada kontrol/tidak dipijat lebih cenderung dengan berat badan normal sebanyak 86,7\%. Hasil uji statistik chi-square p: 0,03 (p.value $\leq 0,05)$, maka dapat diketahui $\mathrm{Ha}$ diterima dan $\mathrm{H}_{0}$ ditolak yang artinya ada pengaruh pijat bayi terhadap peningkatan berat badan di wilayah kerja Puskesmas Sangurara Kota Palu.

\section{PEMBAHASAN}

Hasil analisis data dengan menggunakan uji statistik chi-square diperoleh nilai $p$ value adalah 0,03 pada penelitian ini sehingga dapat diketahui bahwa terdapat pengaruh pijat bayi terhadap peningkatan berat badan di wilayah kerja Puskesmas Sangurara Kota Palu. Jadi, pijat bayi dapat mempengaruhi peningkatan berat badan. Hasil penelitian ini sejalan dengan teori yang dikemukakan oleh Sugiharti (2016) yang menyatakan bahwa Bayi yang dilakukan pemijatan akan memberikan efek lapar pada bayi sehingga frekuensi menyusu bayi akan lebih sering. Hal tersebut disebabkan peningkatan tonus otot saraf vagus yang menyebabkan cabang dari saraf vagus tersebut memudahkan pengeluaran hormon penyerapan makanan dan meningkatkan kadar enzim penyerapan gastrin dan insulin. Sehingga penyerapan terhadap sari makanan akan lebih baik sehingga bayi yang dipijat akan mengalami kenaikan berat badan yang lebih pesat. ${ }^{9}$

Berdasarkan penelitian Irva, dkk (2013) yang dilakukan di Pekanbaru pemijatan terhadap bayi dilakukan selama 2 minggu dapat menunjukan bahwa terdapat pengaruh median berat badan bayi pada kelompok eksperimen, sehingga dapat dikatakan pijat berpengaruh terhadap peningkatan berat badan bayi. Hal ini dibuktikan dari nilai p: 0,01 (p. value < 0,05.). ${ }^{10}$ Berdasarkan hasil penelitian Miah (2010) membuktikan bahwa terdapat pengaruh pijat bayi terhadap kenaikan berat badan bayi umur 10 hari-3 bulan dengan jumlah sampel 60 responden yang dimulai sejak 22 mei- 2011 juli $2011 .{ }^{7}$

Berdasarkan karakteristik yang terdapat dalam penelitian ini dianalisis secara univariat. Hasil analisis karakteristik umur menunjukan bahwa bayi usia 1-2 bulan mengalami peningkatan berat badan yang pesat, sedangkan bayi 3 bulan mengalami peningkatan namun tidak lebih banyak dari usia 1-2 bulan. Menurut asumsi peneliti peningkatan tersebut terjadi karena adanya aktifitas fisik bayi yang masih kurang, frekuensi menyusu yang teratur dan tidur cukup. Sugiharti (2016) mengemukakan penyebab berat badan bayi susah meningkat karena bayi lebih aktif, pertambahan panjang badan, makan dalam jumlah sedikit, gastroesphageal reflux (GER) dan menderita penyakit. Dapat dilihat dari hasil analis di atas pada bayi usia 1-2 bulan dan 3 bulan terdapat perbedaan peningkatan berat badan. ${ }^{11}$ Namun hal tersebut masih dikatakan normal karena pada usia 3 bulan berat badan bayi akan sedikit berkurang yaitu sekitar 133 gram perminggunya hal ini akan berlansung sampai usia 
7 bulan. ${ }^{12}$ Oleh karena itu untuk memepertahankan berat badan maka dilakukan intervensi pijat bayi sebagai alternatifnya.

Berdasarkan hasil analisis jenis kelamin jumlah responden terbanyak adalah lakilaki yaitu 18 responden dan perempuan 12 responden. Menurut asumsi peneliti tidak terdapat berbedaan berat badan yang signifikan antara bayi laki-laki dan perempuan. Menurut Fatmawati (2018) perbedaan jenis kelamin bayi tidak menentukan banyaknya bayi saat menyusu, tetapi ditentukan sesuai dengan kebutuhan bayi. apabila bayi bergerak aktif maka akan banyak kalori yang dibutuhkan sehingga bayi akan lebih banyak saat menyusu. ${ }^{2}$ Adapun distribusi peningkatan berat badan bayi pada kelompok intervensi dan kelompok kontrol tergambarkan bahwa jumlah bayi yang dipijat lebih banyak meningkat yaitu 10 responden atau $66,7 \%$, sedangkan bayi yang tidak dilakukan pijat sebanyak 2 responden atau 13,3\% yang mengalami peningkatan. Jadi, peneliti mengungkapkan bahwa ada pengaruh pijat bayi terhadap peningkatan berat badan.

\section{keterbatasan penelitian}

Keterbatasan dalam penelitian ini yaitu lokasi penelitian atau rumah responden jaraknya saling berjauhan dan pada saat proses penelitian terdapat bayi yang mengalami diare dan panas karena habis mendapatkan imunisasi, sehingga ada bayi yang tidak mengalami peningkat berat badan saat dilakukan pijat.

\section{SIMPULAN DAN SARAN}

Berdasarkan hasil analisa data dan pembahasan mengenai penelitian Pengaruh Pijat Bayi Terhadap Peningkatan Berat Badan maka dapat diambil kesimpulan bahwa terdapat pengaruh yang signifikan antara pijat bayi terhadap peningkatan berat badan di wilayah kerja Puskesmas Sangurara Kota Palu. Hasil penelitian ini dapat disosialisasikan oleh petugas kesehatan, diajarkan oleh petugas kesehatan dan dianjurkan oleh petugas kesehatan di Puskesmas kepada orangtua bayi, sehingga dapat meningkatkan pertumbuhan dan perkembangan pada bayi.

\section{UCAPAN TERIMA KASIH}

Ucapan terima kasih kepada 1) Nasrul, SKM. M.Kes. selaku Direktur Poltekkes Kemenkes Palu atas izin pelaksanaan penelitian ini, 2) Kepala Puskesmas Sangurara beserta staf Kebidanan yang telah membantu proses pengumpulan data penelitian dan 3) Seluruh orangtua bayi yang telah mengizinkan bayinya untuk menjadi responden pada penelitian ini.

\section{DAFTAR PUSTAKA}

1. Marie TN. Asuhan Kebidanan Neonatus, Bayi \& Anak Balita. Jakarta: EGC; 2016.

2. Fatmawati W. Pernah Dengar Atau Merasakan Bayi Cowok Lebih Kuat Menyusu? [Internet]. Akurat.co. 2018. Available from: https://akurat.co/gayahidup/id-267713read-pernah-dengar-atau-merasakan-bayi-cowok-lebih-kuat-menyusu-inipenjelasannya

3. Kementerian Kesehatan R.I. Profil Kesehatan Indonesia Tahun 2017. 2018.

4. Dinas Kesehatan Propinsi Sulawesi Tengah. Profil Kesehatan Provinsi Sulawesi Tengah. Palu; 2017.

5. Dinas Kesehatan Kota Palu. Laporan Tahunan Program Gizi Kota Palu. Palu; 2017.

6. Gürol A, Polat S. The Effects of Baby Massage on Attachment between Mother and their Infants. Asian Nurs Res (Korean Soc Nurs Sci) [Internet]. 2012 Mar;6(1):35-41. Available from: https://linkinghub.elsevier.com/retrieve/pii/S1976131712000072

7. Miah AA. Pengaruh Pijat Bayi Terhadap Kenaikan Berat Badan Bayi Umur 0 -3 Bulan 
Di BPS Saraswati Sleman Yogyakarta Tahun 2010. Universitas Aisyiyah Yogyakarta; 2010.

8. Prasetyono D. Buku Pintar Pijat Bayi. 1st ed. Yogyakarta: Buku Biru; 2013. 29-30 p.

9. Sugiharti RK. Pengaruh Frekuensi Pijat Bayi Terhadap Pertumbuhan (Berat Badan) Bayi Usia 1-3 Bulan Di Desa Karangsari Dan Purbadana. J IIm Kebidanan [Internet]. 2016;7(1):41-52. Available from: http://www.akbidylpp.ac.id/ojs/index.php/Prada/article/download/140/128

10. Irva TS, Hasanah O-, Woferst R-. Pengaruh terapi pijat terhadap peningkatan Berat badan bayi. J Online Mhs Bid IImu Keperawatan [Internet]. 2014;1(2):1-9. Available from: https://jom.unri.ac.id/index.php/JOMPSIK/article/view/4142/4035

11. Lariza P. 5 Penyebab Berat Badan Bayi Susah Naik [Internet]. Mommies Daily. 2016. Available from: https://mommiesdaily.com/2016/12/23/5-penyebab-berat-badan-bayisusah-naik/

12. Halodoc. Ketahui Berat Badan Bayi Sesuai Usia [Internet]. Halodoc. 2018. Available from: https://www.halodoc.com/artikel/ketahui-berat-badan-bayi-sesuai-usia 